\title{
KOMUNIKASI DIGITAL PADA PERUBAHAN BUDAYA MASYARAKAT E-COMMERCE DALAM PENDEKATAN JEAN BAUDRILLARD
}

\author{
Harnina Ridwan ${ }^{1}$, Masrul ${ }^{2}$, Juhaepa $^{3}$ \\ ${ }^{1,2,3}$ Dosen Jurusan Ilmu Komunikasi FISIP Universitas Halu Oleo, Kendari \\ Email: ninaridwan79@yahoo.co.id
}

\begin{abstract}
Abstrak
Penggunaan internet telah mengalami perkembangan yang luar biasa di bidang bisnis terutama pada perusahaan skala besar. Pemanfaatan dan penggunaan teknologi internet diharapkan dapat memberikan manfaat yang besar terhadap dunia bisnis yang kompetitif tersebut. Salah satu jenis implementasi teknologi dalam hal meningkatkan persaingan bisnis dan penjualan produk-produk adalah dengan menggunakan electronic commerce (ecommerce) untuk memasarkan berbagai macam produk atau jasa, baik dalam bentuk fisik maupun digital. Kehadiran e-commerce sendiri telah menggeser budaya masyarakat dalam bertransaksi. Dimana perubahan terjadi ketika yang biasanya masyarakat membutuhkan waktu dan mengharuskan untuk bertransaksi secara konvensional, namun kehadiran ecommerce itu sendiri memberikan ruang pada masyarakat sehingga mampu berbelanja secara online. Hal ini tentunya telah mengubah pola komunikasi masyarakat dalam melakukan transaksi. Yang tidak lagi harus pada komunikasi secara face to face (tatap muka) dalam melakukan transaksi namun bisa teraktualisasikan hanya dengan cara komunikasi dalam virtual. Tujuan penulisan artikel ini adalah untuk mengetahui perubahan sosial pada budaya e-commerce dan dampak dari budaya e-commerce terhadap perilaku konsumtif masyarakat. Penelitian ini merupakan penelitian deskripsi kualitatif. Dengan mengumpulkan berbagai teori, dan data yang terkait, kemudian menganalisis dan menyimpulkannya sehingga penulis dapat menjelaskan perubahan sosial terhadap perilaku konsumtif masyarakat melalui budaya e-commerce. Hasil analisis kami menunjukkan bahwa pergeseran masyarakat pada budaya transaksi online merupakan salah satu pengaruh signifikan karena adanya fasilitas e-commerce. Pergeseran masyarakat pada budaya transaksi online merupakan salah satu pengaruh sinifikan karena adanya fasilitas ecommerce. Kehadiran e-commerce, mampu mengubah cara pandang masyarakat terhadap suatu barang yang di konsumsi. Pembelian suatu produk bukan lagi untuk memenuhi kebutuhan, melainkan karena keinginan, dimana use value (nilai guna) berubah menjadi exchange value (nilai tukar). Didukung oleh perkembangan teknologi informasi, jaringan komunikasi pada dunia virtual kian memfasilitasi dengan adanya e-commerce ini masyarakat bertransaksi secara online tidak lagi harus secara konvensional. Berdasarkan realitas tersebut, dilihat dari perspektif Jean Baudrillard masyarakat lebih digiring pada simulasi-simulasi yang dibentuk oleh media dalam hal ini e-commerce sebagai media alternatif untuk kemudian konsumsilah yang menjadi inti ekonomi. Bukan pada produksi. Manusia lebih memilih untuk mengkonsumsi tanda daripada melihat kegunaan objek itu sendiri.
\end{abstract}

Kata Kunci: Komunikasi, Digital Masyarakat, e-commerce, media, Jean Baudrillard. 


\section{PENDAHULUAN}

Internet merupakan salah satu media paling strategis yang dapat dgunakan untuk mempromosikan barang ataupun jasa. Masyarakat Indonesia yang kini menjadi konsumeris lebih aktif berbelanja dengan menggunakan media online ketimbang berbelanja secara konvensional. Internet saat ini banyak dimanfaatkan oleh para kapitalis untuk meraih keuntungan sebanyak banyaknya. Sehingga masyarakat mudah tergiur dan lebih aktif untuk belanja melalui media online.

Pengguna internet diminati oleh masyarakat kota besarmaupun daerah misalnya berbelanja melalui internet ketimbang harus pergi belanja konvensional. Ini menujukkan bahwa betapa besar pengaruh internet terhadap daya minat pembeli. Internet tidak hanya digunakan sebagai alat komunikasi belaka tetapi juga diberdayakan oleh para kapitalis. Penggunaan internet telah mengalami perkembangan yang luar biasa di bidang bisnis terutama pada perusahaan skala besar.

Internet ditemukan pada tahun 1990-an dan penggunanya semakin meluas karena dipandang memberikan manfaat yang sangat besar bagi kelancaran proses kegiatan bisnis atau usaha salah satunya penerapan sistem oleh perusahaan bisnis. Penerapan teknologi $e$ commerce merupakan salah satu faktor yang penting untuk menunjang keberhasilan suatu produk dari sebuah perusahaan. E-commerce adalah sebuah layanan internet yang dimanfaatkan untuk jual-beli. Mempercepat dan meningkatkan penjualan perusahaan bisnis online memanfaatkan suatu layanan secara on-line berupa e-commerce. Selama ini, sistem penjualan dari pelanggan yang digunakan oleh perusahaan hanya bersifat secara tertulis dan manual. Layanan jasa berupa e-commerce dapat secara cepat dinikmati oleh pelanggan maupun perusahaan sendiri. Segala layanan yang diinginkan oleh para pelanggan dapat segera ditindak lanjuti dengan cepat karna berbasis oline, sehingga perusahaan tersebut mampu memberikan pelayanan terbaik dan tercepat bagi para pelanggan. ${ }^{1}$

Pemanfaatan dan penggunaan teknologi internet diharapkan dapat memberikan manfaat yang besar terhadap dunia bisnis yang kompetitif tersebut. Perusahaan yang mampu bersaing dalam kompetisi tersebut adalah perusahaan yang mampu mengimplementasikan teknologi dan informasi ke dalam perusahaannya. Salah satu jenis implementasi teknologi dalam hal meningkatkan persaingan bisnis dan penjualan produk-produk adalah dengan menggunakan electronic commerce (e-commerce) untuk memasarkan berbagai macam produk atau jasa, baik dalam bentuk fisik maupun digital. Penggunaan teknologi tersebut, berbagai pihak yang terkait dengan perusahaan seperti investor, konsumen, pemerintah akan ikut berperan. Matangnya teknologi internet dan web, teknologi-teknologi ini meningkatkan kemampuan per usahaan yang canggih dalam hal komunikasi bisnis dan dalam hal kemampuannya berbagi informasi, selain itu berbagi sumber daya lain yang bernilai.

Penerapan teknologi e-commerce merupakan salah satu faktor yang penting untuk menunjang keberhasilan suatu produk dari sebuah perusahaan. Mempercepat dan meningkatkan penjualan cepat maka dengan melihat perkembangan teknologi informasi yang sangat pesat tersebut dapat memanfaatkan suatu layanan secara on-line yang berupa $e$ commerce. Layanan electronic commerce (e-commerce) ini maka pelanggan dapat mengakses serta melakukan pesanan dari berbagai tempat. Era teknologi yang canggih saat ini para pelanggan yang ingin mengakses e-commerce tidak harus berada di suatu tempat, hal itu dikarenakan di kota kota besar di Indonesia telah banyak tempat tempat yang menyediakan suatu fasilitas akses internet hanya dengan menggunakan laptop/notebook ataupun dengan Personal Digital Assistant (PDA) dengan menggunakan teknologi wifi.

\footnotetext{
${ }^{1}$ Jurnal Ilmiah Orasi Bisnis - ISSN: 2085-1375 Edisi Ke-VI, November 2011 dikutip pada tanggal 8 November 2017
} 
Maka dari itu saat sekarang sangat diperlukan dan diminati perusahaan-perusahaan yang menerapkan layanan e-commerce. Penggunaan e-commerce di Indonesia masih sangat terbatas. Dari latar belakang yang ada maka penulis akan membahas bagaimana pemanfaaatan e-commerce dalam kepentingan bisnis mereka. ${ }^{2}$

Contoh e-commerce di Indonesia yang sudah popular dan memiliki reputasi yang baik adalah seperti www.bhineka.com, www.blibli.com, www.gramedia.com. Melalui $e$ commerce telah banyak merubah dalam proses jual-beli. Jika dalam suatu jual-beli penjual dan pembeli bertemu, namun jika dengan e-commerce mereka perlu bertemu, mereka berinteraksi dengan melalui internet maupun dengan komunikasi melalui telepon. Proses ini kepercayaanlah yang menjadi modal utama. Kepercayaan kedua belah pihak, dalam proses jual-beli e-commerce bisa terjadi dan terlaksana. Namun dengan perkembangan yang semakin pesat, maka banyak toko online atau e-commerce bermunculan. Baik mereka dengan memanfaatkan blog, social media, website membuat semakin mudahnya dalam jual beli.Dalam hal ini kehadiran e-commerce itu sendiri telah menggeser budaya masyarakat dalam bertransaksi.

Sistem e-commers dapat mempermudah sistem jual beli yang ada di Indonesia. orang-orang juga lebih tertarik untuk membeli barang dengan menggunakan teknologi $e$ commers ketimbang harus pergi belanja konvensional. Berdasarkan fenomena tersebut menunjukkan bahwa tingkat konsumeris masyarakat semakin tinggi disebabkan olah mudahnya untuk membeli barang. Masyarakat tidak lagi melihat harga tetapi lebih kepada kecepatan dan kenayaman belanja melalui e-commers. Selain itu, pembelian barang melalui e-commers bukan lagi atas dasar kebutuhan tetapi lebih kepada trend yang terjadi di lingkungan sosial. Trend yang dimasud adalah banyak masyarakat yang berlomba-lomba untuk membeli barang karna melihat iklan di e-commers sangat menarik dari pada membeli secara konvensional.

Angka pengguna internet dari tahun ke tahun semakin tinggi yang membuat perusahaan bisnis semakin gencar untuk mempromosikan barangnya menggunakan sistem $e$ commers. Pada tahun 2012, suatu perusahaan e-commerce di Indonesia mencatat bahwa $41 \%$ penjualan mereka berasal dari Jakarta, tapi enam bulan selanjutnya angka ini turun menjadi $22 \%$. Ini menunjukkan bahwa tidak hanya konsumen di Jakarta saja yang rutin berbelanja online, konsumen di luar Jakarta pun tidak ingin ketinggalan mengikuti perkembangan zaman dengan menunjukkan kontribusi mereka pada pasar $e$-commerce di Indonesia.

Berdasarkan realitas tersebut, maka fokus dalam paper ini adalah bagaimana bagaimana perubahan sosial pada budaya e-commerce dan bagaimana dampak dari budaya e-commerce. Penelitian ini bertujuan untuk mengetahui perubahan sosial pada masyarakat dengan adanya e-commerce membawa pada pergeseran mewabahnya budaya bisnis online di masyarakat. Kehadiran e-commerce perubahan sosial pada masyarakat yang semakin konsumtif.

\section{KAJIAN TEORITIS \\ Perubahan Sosial}

Menurut Selo Soemardjan, perubahan sosial adalah perubahan yang terjadi pada lembaga kemasyarakatan di dalam suatu masyarakat yang mempengaruhi sistem sosial, termasuk didalamnya nilai-nilai, sikap-sikap dan pola prilaku diantara kelompok dalam masyarakat menurutnya, antara perubahan sosial dan perubahan kebudayaan memiliki satu aspek yang sama yaitu keduanya bersangkut paut dengan suatu penerimaan cara-cara baru

\footnotetext{
${ }^{2}$ Jurnal Ilmiah Orasi Bisnis - ISSN: 2085-1375 Edisi Ke-VI, November 2011 dikutip pada tanggal 30 Mei 2015
} 
atau suatu perbaikan cara masyarakat dalam memenuhi kebutuhannya. Selain itu perubahan sosial tidak dapat dilepaskan dari perubahan kebudayaan karena kebudayaan merupakan hasil dari adanya masyarakat, sehingga tidak akan adanya kebudayaan apabila tidak ada masyarakat yang mendukungnya dan tidak ada satupun masyarakat yang tidak memiliki kebudayaan. $^{3}$

Perubahan sosial itu bersifat umum meliputi perubahan berbagai aspek dalam kehidupan masyarakat, sampai pada pergeseran persebaran umur, tingkat pendidikan dan hubungan antar warga. Perubahan aspek-aspek tersebut terjadi perubahan struktur masyarakat serta hubungan sosial. Jadi perubahan sosial juga dapat diartikan sebagai perubahan yang terjadi dalam masyarakat atau dalam hubungan interaksi, yang meliputi berbagai aspek kehidupan. Sebagai akibat adanya dinamika anggota masyarakat dan yang telah didukung oleh sebagian besar anggota masyarakat.

\section{Simulasi, Simulacra dan Hiperrealitas Menurut J. Baudrillard}

Menurut Baudrillard, kita hidup dalam era dimana masyarakat tidak lagi didasarkan pada pertukaran barang materi yang berdaya guna, melainkan pada komoditas sebagai tanda dan simbol yang signifikasinya sewenang-wenang (arbitrer) dan tergantung kesepakatan dalam apa yang disebut kode. Baudrillard menganaogikan konsumsi pada masyarakat masa kini dengan bahasa dan sistem tanda dalam masyarakat primitive. Manusia sepanjang masa membutuhkan symbol yang dipuja dan disembah. Masyarakat masa kini pun punya kultuskultus sendiri seperti terhadap kemasan benda-benda, citra (image), televise, serta terhadap konsep kemajuan (progress) dan pertumbuhan (growth). ${ }^{4}$

Hiperrealitas adalah konsep yang dikemukakan oleh Jean Baudrillard, sebuah konsep dimana realitas yang dalam konstruksinya tidak bisa dilepaskan dari produksi dan permainan tanda-tanda yang melampaui realitas aslinya (Hyper-sign). Hiperrealitas menciptakan suatu kondisi dimana kepalsuan bersatu dengan keaslian, masa lalu berbaur dengan masa kini, fakta bersimpang siur dengan rekayasa, tanda melebur dengan realitas, dusta bersenyawa dengan kebenaran. Hiperrealitas menghadirkan model-model kenyataan sebagai sebuah simulasi bagi penikmatnya (simulacrum). Simulasi adalah suatu proses dimana representasi (gambaran) atas dasar tanda-tanda realitas (sign of reality), dimana tanda-tanda tersebut justru menggantikan objek itu sendiri, dimana representasi itu menjadi hal yang lebih penting dibandingkan objek tersebut. ${ }^{5}$

Simulasi hadir bukan untuk melukiskan realitas yang direpresentasikannya, tetapi mereka hadir hanya untuk mengacu pada dirinya sendiri \& melampaui realitas aslinya. Dalam penjelasannya, seperti pada kondisi masyarakat saat ini, media mempunyai suatu peranan penting dalam penyebaran realitas, dimana penyebaran tersebut akan diserap oleh konsumen media (masyarakat). Kemudian masyarakat tersebut menerima informasi dan setelah itu menyerapnya. Hal ini membuat masyarakat menganggap bahwa informasi tersebut sebagai suatu kebenaran, yang padahal informasi tersebut hanyalah sebuah realitas semu. Dari titik ini, J. Baudrillard menggunakan istilah simulacrum yang merupakan cara pemenuhan kebutuhan masyarakat kontemporer akan sebuah tanda, yang pada artinya suatu realitas itu sengaja diciptakan untuk menggambarkan suatu realitas, akan tetapi realitas yang sesungguhnya mungkin tidak ada, dimana objek realitas itu sudah tidak berfungsi lagi sebagai tanda, sehingga dapat dikatakan bahwa realitas palsu itu dianggap sebagai realitas

\footnotetext{
${ }^{3}$ Selo Soemardjan, Perubahan Sosial di Yogyakarta, (Yogyakarta: Gama Press, 1986) h. 21

${ }^{4}$ Sutrisno, Mudji \& Hendar Putranti, Teori-Teori Kebudayaan, (Yogyakarta : Penerbit Kanisius, 2005), hal. 263)

${ }^{5}$ John, Lechte, 50 Filusuf Kontemporer, (Yogyakarta: Penerbit Kanisius, 2001), hal. 23
} 
yang sesungguhnya karena mayarakat saat ini telah hidup di era postmodern, bukan lagi era modernitas, dan ini ditandai dengan adanya beragam simulasi.

Proses simulasi ini mengarah pada simulacra. Simulacra adalah ruang dimana mekanisme simulasi berlangsung. Merujuk pada teori Baudrillard, terdapat tiga tingkatan simulacra: Pertama, simulacra yang berlangsung semenjak era Renaisans hingga permulaan Revolusi Industri. Simulacra pada tingkatan ini merupakan representasi dari relasi alamiah berbagai unsur kehidupan. Kedua, simulacra yang berlangsung seiring dengan perkembangan era industrialisasi. Pada tingkatan ini, telah terjadi pergeseran mekanisme representasi akibat dampak negatif industrialisasi. Ketiga, simulacra yang lahir sebagai konsekuensi berkembangnya ilmu dan teknologi informasi. ${ }^{6}$

Dalam wacana simulasi, manusia mendiami ruang realitas, dimana perbedaan antara yang nyata dan yang semu, yang asli dan yang palsu sangat tipis. Dunia-dunia buatan semacam Disneyland, Universal Studio, China Town, Las Vegas atau Beverlly Hills, yang menjadi model realitas-semu Amerika adalah representasi paling tepat untuk menggambarkan keadaan ini.

Kesatuan inilah yang disebut Baudrillard sebagai simulacra atau simulacrum, sebuah dunia yang terbangun dari sengkarut nilai, fakta, tanda, citra dan kode. Proses simulasi ini kemudian mendorong lahirnya term 'hiperrealitas', di mana tidak ada lagi yang lebih realistis sebab yang nyata tidak lagi menjadi rujukan. Baudrillard memandang era simulasi dan hiperrealitas sebagai bagian dari rangkaian fase citraan yang berturut-turut: Pertama, citraan adalah refleksi dasar realitas. Kedua, ia menutupi dan menyelewengkan dasar realitas. Ketiga, ia menutupi ketidakadaan realitas. Keempat, ia melahirkan ketidakberhubungan pada berbagai realitas apapun, ia adalah kemurnian simulakrum itu sendiri. $^{7}$

Dunia menurut Baudrillard, didominasi oleh "simulacrum". Ini adalah konsep yang diperkenalkan Jean Baudrillard yang mewakili tiadanya lagi batas antara yang nyata dengan yang semu. Dunia telah menjadi dunia imajiner. Baudrillard memberikan contoh Disneyland. Disneyland adalah suatu dunia imajiner di mana segala sesuatunya bersifat futuristik, dan mimpi-mimpi. Disneyland telah menjadi bius bagi sebagian besar konsumen kelas menengah sehingga selalu dijejali orang sepanjang tahunnya.

Disneyland menurut Baudrillard merupakan bentuk pemujaan berhala mutakhir. Pemujaan yang menunjukkan betapa irasionalnya perilaku konsumtif orang-orang yang rela mengantri berjam-jam, membayar puluhan dollar hanya untuk memuaskan nafsu, insting, dorongan dan impuls. Kolektivitas yang muncul adalah semu. Segerombolan orang riang gembira menikmati kebersamaan mereka. Kemudian kembali terpecah menjadi individuindividu yang menjemukan dengan rutinitas yang itu-itu saja. Ini adalah sebuah simulacrum. ${ }^{8}$

Jean Baudrilard menggunakan juga istilah hiperialitas untuk menjelaskan perekayasaan (dalam pengertian distorsi) makna di dalam media. Hiperealitas komunikasi, media dan makna menciptakan satu kondisi, di mana kesemuanya dianggap lebih nyata daripada kenyataan, dan kepalsuan dianggap lebih benar daripada kebenaran. Isu lebih dipercaya ketimbang informasi, rumor dianggap lebih benar ketimbang kebenaran. Kita tidak dapat lagi membedakan antara kebenaran dan kepalsuan, antara isu dan realitas.

\footnotetext{
${ }^{6}$ John Lechte, 50 Filusuf Kontemporer, (Yogyakarta: Penerbit Kanisius, 2001), hal. 27

${ }^{7}$ ibid hal. 23

${ }^{8}$ Jurnal Ilmu Perpustakaan \& Kearsipan Khizanah Al-Hikmah,Vol.2No.1,hlm.38-48. Dikases tanggal 8 November 2017
} 
Berkembangnya hiperealitas komunikasi dan media tidak terlepas dari perkembangan teknologi yang telah berkembang mencapai teknologi simulasi ${ }^{9}$

\section{Perkembangan E-Commers di Indonesia}

E-commerce atau disebut juga perdagangan elektronik merupakan aktivitas yang berkaitan dengan pembelian, penjualan, pemasaran barang ataupun jasa dengan memanfaatkan sistem elektronik seperti internet atau jaringan komputer. E-commerce melibatkan aktivitas yang berhubungan dengan proses transaksi elektronik seperti transfer dana elektronik, pertukaran data elektronik, sistem pengelolaan data inventori yang dilakukan dengan sistem komputer ataupun jaringan komputer dan lain sebagainya. Dalam teknologi informasi e-commerce dapat dikategorikan sebagai dari e-business dimana $e$ business memiliki cakupan yang lebih luas dari segi aktivitas ataupun jenis-jenis kegiatan yang dilakukannya. ${ }^{10}$

Perkembangan e-commerce di Indonesia sendiri telah ada sejak tahun 1996, dengan berdirinya Dyviacom Intrabumi atau D-Net (www.dnet.net.id) sebagai perintis transaksi online. Wahana transaksi berupa mall online yang disebut D-Mall (diakses lewat D-Net) ini telah menampung sekitar 33 toko online/merchant. Produk yang dijual bermacam-macam, mulai dari makanan, aksesori, pakaian, produk perkantoran sampai furniture. Selain itu, berdiri pula http://www.ecommerce-indonesia.com/, tempat penjualan online berbasis internet yang memiliki fasilitas lengkap seperti adanya bagian depan toko (store front) dan shopping cart (keranjang belanja). Selain itu, ada juga Commerce Net Indonesia - yang beralamat di http://isp.commerce.net.id/. Sebagai Commerce Service Provider (CSP) pertama di Indonesia, Commerce Net Indonesia menawarkan kemudahan dalam melakukan jual beli di internet. Commerce Net Indonesia sendiri telah bekerjasama dengan lembagalembaga yang membutuhkan e-commerce, untuk melayani konsumen seperti PT Telkom dan Bank International Indonesia. Selain itu, terdapat pula tujuh situs yang menjadi anggota Commerce

Net Indonesia, yaitu Plasa.com, Interactive Mall 2000, Officeland, KompasCyber Media, Mizan Online Telecommunication Mall dan Trikomsel.

Perkembangan e-commerce di Indonesia pada tahun-tahun mendatang. E-commerce sebetulnya dapat menjadi suatu bisnis yang menjanjikan di Indonesia. Hal ini tak lepas dari potensi berupa jumlah masyarakat yang besar dan adanya jarak fisik yang jauh sehingga $e$ commerce dapat dimanfaatkan dengan maksimal. Sayangnya, daya beli masyarakat yang masih rendah dan infrastruktur telekomunikasi yang tidak merata di daerah-daerah lainnya membuat e-commerce tidak begitu populer. Hal ini tak lepas dari jumlah pengguna internet di Indonesia yang hanya sekitar 8 juta orang dari 215 juta penduduk. Selain itu, e-commerce juga belum banyak dimanfaatkan oleh perusahaan-perusahaan di Indonesia.

Ada beberapa bentuk e-commerce di Indonesia yakni bisnis e-commerce bisa dibedakan menjadi beberapa jenis berbeda berdasarkan dari bagaimanakah layanan yang diberikan oleh $e$-commerce tersebut. Seperti halnya beberapa nama perusahaan $e$-commerce besar TokoBagus, Kaskus FJB, hingga Lazada memiliki bentuk bisnis e-commerce yang berbeda satu dengan yang lain.

\footnotetext{
9 Jurnal Ilmu Perpustakaan \& Kearsipan Khizanah Al-Hikmah,Vol.2No.1,hlm.38-48. Dikases tanggal 8 November 2017

10 http://www.patartambunan.com/pengertian-e-commerce-manfaat-serta-keuntungan-e-commercel diakses pada tanggal 9 November 2017
} 


\section{METODE PENELITIAN}

Penelitian ini merupakan jenis penelitian deskripsi kualitatif. Penelitian ini menggunakan pendekatan teoritis yaitu mengumpulkan beberapa konsep kemudian menganalisisnya. Dengan mengumpulkan berbagai teori, dan data yang terkait, kemudian menganalisis dan menyimpulkannya sehingga dapat menjelaskan perubahan sosial terhadap perilaku konsumtif masyarakat melalui budaya $e$-commerce.

\section{ANALISIS PEMBAHASAN}

Pergeseran masyarakat pada budaya transaksi online merupakan salah satu pengaruh adanya fasilitas e-commerce. Perniagaan, penjualan, pembelian, pemasaran, dan pendistribusian online sekarang menjadi budaya baru pada masyarakat. Data dari Social Research \& Monitoring soclab.comenunjukkan, pada 2015 pengguna internet di Indonesia mencapai 93,4 juta dengan 77 persen di antaranya mencari informasi produk dan belanja online. Pada 2016, jumlah online shopper mencapai 8,7 juta orang dengan nilai transaksi sekitar 4,89 miliar dolar AS. ${ }^{11}$

Jumlah pembeli e-commerce akan terus meningkat seiring dengan bertumbuhnya penggunaan smartphone, penetrasi internet di Indonesia, penggunaan kartu debit dan kredit, dan tingkat kepercayaan konsumen untuk berbelanja secara online. Jika kita melihat Indonesia sebagai Negara kepulauan yang sangat luas, e-commerce adalah pasar yang berpotensi tumbuh sangat besar di Indonesia. Menteri Komunikasi dan Informatika Rudiantara mengatakan nilai transaksi di industri e-commerce tahun ini yang ia harapkan. Untuk tahun 2016 Transaksi E-commerce Indonesia ditaksir mencapai Rp394 Triliun. Ini bukan angka yang kecil. Dari tahun ke tahun jumlah pembeli e-commerce semakin meningkat.

Dibandingkan dengan beberapa tahun lalu pada tahun 2012, suatu perusahaan $e$ commerce di Indonesia mencatat bahwa $41 \%$ penjualan mereka berasal dari Jakarta. Data dari lembaga riset ICD memprediksi bahwa pasar e-commerce di Indonesia akan tumbuh 42\% dari tahun 2012-2015. Angka ini lebih tinggi jika dibandingkan negara lain seperti Malaysia (14\%), Thailand (22\%), dan Filipina (28\%). ${ }^{12}$ Sedangkan pada tahun 2012, suatu perusahaan e-commerce di Indonesia mencatat bahwa $41 \%$ penjualan mereka berasal dari Jakarta. Data dari lembaga riset ICD memprediksi bahwa pasar e-commerce di Indonesia akan tumbuh $42 \%$ dari tahun 2012-2015. Angka ini lebih tinggi jika dibandingkan negara lain seperti Malaysia (14\%), Thailand (22\%), dan Filipina (28\%). ${ }^{13}$

Pertumbuhan jumlah pengakses dan pembeli dengan menggunakan sistem $e$ commerce dari tahun ke tahun semakin meningkat. Hal ini disebabkan oleh beberapa faktor, salah satunya daya akses masyarakat terhadap internet sangat tinggi sehingga memungkinkan masyarakat lebih memilih untuk berbelanja online daripada belanja konvensional. Selain itu, produk yang ditawarkan media online lebih variatif dengan menggunakan berbagai iklan yang bisa menarik minat daya beli masyarakat. Ini juga menjadi salah satu kelebihan media online yang menggunakan komunikasi digital dalam memasarkan barang dan jasa.

Kehadiran e-commerce saat ini memberi perubahan budaya masyaarkat khususnya dalam aspek pemasaran. Masyarakat memanfaatkan situs e-commerce dengan lahan bisnis baru dan juga menstimuli masyarakat untuk lebih konsumtif karena kehadiran e-commerce memudahkan transaksi jual beli ataupun mengkonsumsi barang tanpa batasan ruang dan

\footnotetext{
${ }^{11}$ http://www.tribunnews.com/bisnis/2017/02/20/transaksi-e-commrece-di-indonesia-pada-2016-mencapai-489miliar-dolar-as diakesis tanggal 10 november 2017

${ }^{12} \mathrm{http} / / /$ startupbisnis.com/data-statistik-mengenai-pertumbuhan-pangsa-pasar-e-commerce-di-indonesia-saatini/ diakses pada tanggal 9 Novmber 2017

${ }^{13}$ Ibid. hal 2
} 
waktu. Jika dalam transaksi pasar konvensional mengharuskan pertemuan fisik dan keterbatasan waktu, e-commerce menghadirkan cara dalam berbelanja kapanpun dan dimanapun. Untuk itu salah satu dampak dari kehadiran e-commerce adalah budaya berbelanja yang menstimuli masyarakat untuk lebih konsumtif karena kemudahan akses dalam berbelanja.

Berdasarkan informasi dari Heppy Tranggono, Ketua Indonesian Islamic Business Forum (IIBF) di salah satu media Solo, CyberNews. Bahwa Masyarakat Indonesia dinilai sangat konsumtif. Terbukti bahwa saat ini, Indonesia menduduki peringkat ke dua sebagai negara paling konsumtif dibawah Singapura.

Kehadiran e-commerce, mampu mengubah cara pandang masyarakat terhadap budaya konsumtif. Pembelian suatu produk bukan lagi untuk memenuhi kebutuhan, melainkan karena keinginan, dimana use value (nilai guna) berubah menjadi exchange value (nilai tukar). Misalnya orang lebih mau membeli televisi dari pada buku artinya orang membeli produk yang tidak terlalu bermanfaat karena adanya trigger atau sebuah rangsangan untuk memiliki produk melalui bisnis online. E-commerce difasilitasi oleh perkembangan teknologi informasi melalui jaringan komunikasi dunia virtual. Faktanya adalah masyarakat bertransaksi secara online tidak lagi harus secara konvensional. Menurut Adji Gunawan, Associate Partner dan Technology Competency Group Head Andersen Consulting, secara umum ada tiga tahapan menuju e-commerce, yakni: presence (kehadiran), interaktivitas dan transaksi.

Transaksi e-commerce menyajikan tiga tahapan, Pertama presence atau kehadiran merupakan aspek krusial ketika berlangsungnya transaksi secara e-commerce yakni menghadirkan penjual dan pembeli dalam dunia virtual atau belanja secara online meskipun terbatas pada pertemuan fisik. Kedua, interkativitas. Artinya aktifitas yang terhubung dalam beberapa tahapan. Berawal dalam pemesanan barang memanfaatkan situs jearing sosial lalu mentransfer dana sesuai pemesanan dan penjual mengirimkan barang yang dipesan lalu pembeli atau pemesan mengkonfirmasi kembali ketika barang sudah sampai ke konsumen. Hal tersebut memperlihatkan proses komunikasi melalui transaksi secara online. Ketiga transaksi, dipresentasekan pada saat berlangsungnya proses komunikasi. Kenyataanya adalah penggunaan e-commerce memberikan dampak budaya pada masyarakat secara unik berbeda dengan proses belanja konvensional.

Kajian teoritis dalam tulisan ini menggunakan pendekatan atau perspektif dari Jean Baudrillard yang mengembangkan teori untuk berusaha memahami sifat dan pengaruh komunikasi massa. Ia mengatakan media massa menyimbolkan zaman baru di mana bentuk produksi dan konsumsi lama telah memberikan jalan bagi semesta komunikasi yang baru. Kajian teoritis ini mengarah pada new media dan penggunaannya seperti fenomena sekarang ini yakni e-commerce (sistem belanja online).

E-commerce (sistem belanja online) merupakan keadaan hiperrealitas yang membuat masyarakat modern menjadi berlebihan dalam pola mengkonsumsi sesuatu yang tidak jelas esensinya. Kebanyakan dari masyarakat ini mengkonsumsi bukan karena kebutuhan ekonominya melainkan karena pengaruh model-model dari simulasi yang menyebabkan gaya hidup masyarakat menjadi berbeda. Media membuat masyarakat jauh dari kenyataan. Masyarakat secara tidak sadar terpengaruh oleh simulasi dan tanda (simulacra) yang ada di tengah kehidupan kita seperi pada kehadiran e-commerce telah menggeser pada era digital sehingga menstimuli khalayak untuk lebih konsumtif. Konsumsi yang digunakan bukan lagi pada tahapan use value tapi bergeser pada exchange value.

Konsep Baudrillard mengenai simulasi yakni fokus pada penciptaan kenyataan melaui seduatu yang berhubungan dengan "mitos" yang tidak dilihat kebenarannya dalam kenyataan. Model ini menjadi faktor penentu pandangan kita tentang kenyataan. Segala yang 
dapat menarik minat manusia - seperti model pakaian, peraatan rumah tangga, alat fitnes ditayangkan melalui berbagai media online dengan model-model yang ideal, sehingga batas antara simulasi dan kenyataan menjadi tercampur aduk sehingga menciptakan hiperrealitas di mana yang nyata dan yang tidak nyata menjadi tidak jelas.

Fenomena yang terjadi dilihat dari perspektif Jean Baudrillard masyarakat lebih digiring pada simulasi-simulasi yang dibentuk oleh media dalam hal ini e-commerce sebagai media alternatif untuk kemudian konsumsilah yang menjadi inti ekonomi. Bukan pada produksi. Masyarakat lebih memilih untuk mengkonsumsi tanda daripada melihat kegunaan objek itu sendiri. Contoh: ada faktanya sebagian orang, ketika berbelanja online, maka keinginan memiliki dan brand menjadi prioritas. Karena ketika sudah memiliki, maka mengkonsumsi bukan secara verbal atau fungsi tapi secara simbol. Simbol yang secara implisit eksotis, kharismatik dan modern.

Perilaku konsumtif sendiri didefinisikan oleh Solomon (2002:453) sebagai sebuah studi tentang proses yang menghubungkan individu atau grup yang terpilih terhadap pembelian, penggunaan produk, ide, atau pengalaman untuk memuaskan kebutuhan dan hasrat. Dimesi komunikasi yang terdapat pada kehadiran e-commerce ini sendiri telah mengubah membawa pada budaya masyarakat yang dapat bertransaksi secara online. Menurut Adji Gunawan, secara umum ada tiga tahapan menuju e-commerce, yakni: presence (kehadiran), interaktivitas dan transaksi. Sebuah gejala yang tengah mewabah dalam situs kultural mayarakat dewasa ini adalah fenomena kelahiran tren-tren baru. Masyarakat terobsesi untuk menghadirkan tren-tren revolusioner dalam menanggapi gejolak perubahan jaman. Fenomena ini hakikatnya merupakan implementasi dari dinamika kebudayaan bersifat terbuka untuk mengalami perubahan.

\section{KESIMPULAN}

Pergeseran masyarakat pada budaya transaksi online merupakan salah satu pengaruh signifikan karena adanya fasilitas e-commerce. Pergeseran masyarakat pada budaya transaksi online merupakan salah satu pengaruh sinifikan karena adanya fasilitas e-commerce. Kehadiran e-commerce, mampu mengubah cara pandang masyarakat terhadap suatu barang yang di konsumsi. Pembelian suatu produk bukan lagi untuk memenuhi kebutuhan, melainkan karena keinginan, dimana use value (nilai guna) berubah menjadi exchange value (nilai tukar). Perkembangan teknologi informasi, jaringan komunikasi pada dunia virtual kian memfasilitasi dengan adanya e-commerce ini masyarakat bertransaksi secara online tidak lagi harus secara konvensional.

Berdasarkan fenomena-fenomena tersebut, dimana dalam perspektif Jean Baudrillard masyarakat lebih digiring pada simulasi-simulasi yang dibentuk oleh media dalam hal ini $e$ commerce sebagai media alternatif untuk kemudian konsumsilah yang menjadi inti ekonomi. Bukan pada produksi. Manusia lebih memilih untuk mengkonsumsi tanda daripada melihat kegunaan objek itu sendiri.

\section{REFERENSI}

Azwar, M. (2014). Teori Simulakrum Jean Baudrillard dan upaya pustakawan mengidentifikasi informasi realitas. Jurnal Ilmu Perpustakaan \& Kearsipan Khizanah Al-Hikmah,Vol.2No.1.

Herlianto. 1997. Urbanisasi, Pembangunan dan Kerusuhan Kota. Bandung: P.T Alumni.

Lechte, John. 2001. 50 Filusuf Kontemporer. Yogyakarta: Kanisius, 2001.

Jurnal Ilmiah Orasi Bisnis - ISSN: 2085-1375 Edisi Ke-VI.

Soaemardjan, Selo. 1986. Perubahan Sosial di Yogyakarta. Yogyakarta. 
Sutrisno, Mudji \& Hendar Putranti. 2005. Teori-Teori Kebudayaan. Yogyakarta : Penerbit Kanisius.

http://www.patartambunan.com/pengertian-e-commerce-manfaat-serta-keuntungan-ecommerce

http://startupbisnis.com/data-statistik-mengenai-pertumbuhan-pangsa-pasar-e-commerce-diindonesia-saat-ini/ diakses pada tanggal 9 Novmber 2017

http://www.tribunnews.com/bisnis/2017/02/20/transaksi-e-commrece-di-indonesia-pada2016-mencapai-489-miliar-dolar-as diakesis tanggal 10 november 2017 